\title{
Navigation System for a Deep-sea ROV Fusing USBL, DVL, and Heading Measurements
}

\author{
Pan-Mook Lee, Hyungwon Shim, Hyuk Baek, Banghyun Kim*, \\ Jin-Yeong Park ${ }^{*}$, Bong-Huan Jun ${ }^{*}$ and Seong-Yeol Yoo* \\ "Korea Research Institute of Ships \& Ocean Engineering, Marine Robotics Laboratory, Daejeon, Korea
}

USBL, DVL과 선수각 측정신호를 융합한 심해 무인잠수정의 항법시스템

\author{
이판묵 ${ }^{*}$ 심형원 ${ }^{*}$ 백혁* - 김방현 ${ }^{*}$ 박진영 ${ }^{*}$ 전봉환 ${ }^{*}$ 유승열* \\ "선박해양플랜트연구소 수중로봇연구실
}

KEY WORDS: Underwater navigation 수중항법, Ultra-short baseline (USBL) 초단기선 초음파 위치추적시스템, Doppler velocity log (DVL) 도플러 속도계, Fusion 신호융합, Kalman filter 칼만필터

\begin{abstract}
This paper presents an integrated navigation system that combines ultra-short baseline (USBL), Doppler velocity log (DVL), and heading measurements for a deep-sea remotely operated vehicle, Hemire. A navigation model is introduced based on the kinematic relation of the position and velocity. The system states are predicted using the navigation model and corrected with the USBL, DVL, and heading measurements using the Kalman filter. The performance of the navigation system was confirmed through re-navigation simulations with the measured data at the Southern Mariana Arc submarine volcanoes. Based on the characteristics of the measurements, the design process for the parameters of the system modeling error covariance, measurement error covariance, and initial error covariance are presented. This paper reviews the influence of the outliers and blackout of the USBL and DVL measurements, and proposes an outlier rejection algorithm that is robust to USBL blackout. The effectiveness of the method is demonstrated with re-navigation for the data that includes USBL blackouts.
\end{abstract}

\section{1. 서 론}

심해 무인잠수정(ROV, Remotely operated vehicle) 해미래는 2016년 3월 마리아나 해저화산 탐사에 투입됐다(Lee et al., 2016). 이 탐사에서 해미래의 위치는 선상에 설치된 USBL(Ultra short baseline)을 이용하여 일정간격으로 모니터링 되었고, DVL (Doppler velocity $\log$ )과 AHRS(Attitude heading reference system) 를 기반으로 하는 추측항법(DR, Dead- reckoning)을 이용하여 짧 은 시간동안 위치를 추적했다. 항법오차가 누적되어 USBL과 $10 \mathrm{~m}$ 이상 차이가 커질 때 USBL 신호로 추측항법 상태변수를 리셋 하는 방식으로 운용되었다. 이 방식은 항법오차가 단속적 으로 증가하여 정밀하게 경로를 추적하기 어려우므로, USBL과 DVL 신호를 융합하는 안정한 항법시스템 개발이 요구되었다.

무인잠수정의 수중항법을 위한 USBL과 DVL 신호를 융합하 는 방법은 다양하게 연구되고 있다. Rigby et al.(2006)는 비정규 분포의 USBL 신호를 갖는 AUV(Autonomous underwater vehicle)
에 대하여 파티클 필터를 이용해서 $\mathrm{DVL}$ 기반의 추측항법과 USBL을 융합하는 위치추정법을 연구했다. Ridao et al.(2011) 및 Ribas et al.(2012)은 USBL 측정신호의 시간지연을 고려한 DVL 융합을 연구하여 AUV의 수중항법에 적용했다. Vasilijevic et al. (2012)는 천해역에서의 USBL과 DVL 신호융합을 연구했고 아 웃라이어 식별 및 제거법에 대하여 논의했다. Lee et al.(2007)는 관성항법알고리듬에 거리정보를 융합한 복합항법 알고리듬을 제안했고, 2015년에는 USBL, DVL 및 IMU(Inertial measurement unit) 신호를 융합하는 연구를 수행했다(Lee et al., 2015). 이 연 구에서 IMU 신호를 이용하는 무인잠수정은 속도변화가 크지 않으므로 관성센서를 이용한 수중항법이 DVL을 '이용하는 추 측항법과 비교해 거의 유사했다. 또한 Sane-Muntadas et al. (2015)은 USBL을 이용하는 도킹용 AUV에 대하여 선수각-방위 각과 위치 각각에 대하여 칼만필터를 직렬로 설계하고 공분산 에서 얻어지는 정보를 이용하여 도킹 확률을 평가하는 방법을 제안했다.

Received 3 May 2017, revised 16 May 2017, accepted 28 July 2017

Corresponding author Pan-Mook Lee: +82-42-866-3810, pmlee@kriso.re.kr

(C) 2017, The Korean Society of Ocean Engineers

This is an open access article distributed under the terms of the creative commons attribution non-commercial license (http://creativecommons.org/licenses/by-nc/3.0) which permits unrestricted non-commercial use, distribution, and reproduction in any medium, provided the original work is properly cited. 
한편 LBL(Long baseline)과 DVL 신호를 융합하는 연구도 진 행되었다. Kinsey and Whitcomb(2004)은 LBL과 DVL을 융합하 여 정밀항법과 제어가 가능한 DVLNAV를 개발했다. Miller et al.(2010)은 확장 칼만필터를 적용하여 관성항법시스템과 LBL 및 DVL 신호를 융합했으며, $\mathrm{AUV}$ 의 이동에 무관하게 위치를 추정하는 기법을 제안했다. Kang et al.(2017)은 무인잠수정의 수 평면 운동에 관한 기구학적 관계식을 이용하고 GPS 신호를 $\mathrm{AUV}$ 의 추측항법의 보조신호로 이용하는 방법을 연구했다.

본 논문은 고가의 관성센서 사용을 배제하고 USBL과 DVL 및 선수각 신호를 융합하는 통합항법시스템에 관한 연구로서, Lee et al.(2017)가 발표한 논문 내용을 보충하고 확장한 것이다. 항법 모델은 동력학 관계식을 기반으로 하며, 칼만필터를 이용 해 신호주기가 상이한 비동기 다중 센서를 이용해 파라미터를 업데이트하는 항법시스템을 제안한다. 제안한 항법시스템은 마 리아나 해저화산 탐사에서 해미래를 활용해 얻은 데이터를 이 용하여 유효성을 검증했다. 본 논문은 해미래에 탑재된 센서의 특성과 실해역 측정데이터의 특성을 반영하여 항법시스템의 파 라미터를 선정하는 과정을 상술했고, USBL과 DVL 측정신호의 블랙아웃 특성을 고려하여 아웃라이어를 판정하는 방법을 제안 했다. 블랙아웃이 존재하는 알키안 블랙스모커 탐사(Lee et al., 2016) 데이터에 적용한 시뮬레이션(Re-navigation)을 통해 통합 항법시스템의 유효성을 검토했다.

\section{USBL-DVL-선수각 통합 항법시스템}

\section{1 항법시스템 모델링}

무인잠수정은 횡동요와 종동요가 크지 않다면 커플링 효과가 작아 6자유도 운동을 수평면과 수직면 3자유도 운동으로 나누 어 해석될 수 있다. 잠수정에 장착된 $\mathrm{DVL}$ 측정 속도는 선체고 정좌표계 기준이며, 수상 선박에서 USBL을 이용해 얻는 잠수정 측정 위치는 지구고정좌표계 기준이다. Fig. 1은 해저면에서 운 항하는 무인잠수정에 고정된 선체고정좌표계와 지구좌표계를 나타낸다.

잠수정의 횡동요와 종동요가 작다면, 시간 $k+1$ 의 잠수정 위 치와 속도는 시간 $k$ 에서 잠수정의 수평면 속도와 가속도를 이 용하여 다음으로 표현할 수 있다.

$$
x_{k+1}=f\left(x_{k}, a_{k}\right)
$$

$$
\left\{\begin{array}{c}
X \\
Y \\
Z \\
\psi \\
u \\
v \\
w \\
r
\end{array}\right\}_{k+1}=\left\{\begin{array}{c}
X+\left(u \Delta t+a_{x} \Delta t^{2} / 2\right) \sin \psi+\left(v \Delta t+a_{y} \Delta t^{2} / 2\right) \cos \psi \\
Y+\left(u \Delta t+a_{x} \Delta t^{2} / 2\right) \cos \psi-\left(v \Delta t+a_{y} \Delta t^{2} / 2\right) \sin \psi \\
Z+w \Delta t+a_{z} \Delta t^{2} / 2 \\
\psi+r \Delta t+a_{r} \Delta t^{2} / 2 \\
u+a_{x} \Delta t \\
u+a_{y} \Delta t \\
w+a_{z} \Delta t \\
r+a_{r} \Delta t
\end{array}\right\}_{k}
$$

$X, Y, Z, \psi$ 는 지구고정좌표계, $u, v, w, r$ 은 선체고정좌표계 기준이고, $a$ 는 가속도 성분을 나타낸다. 시간증분 사이에 가속 도 변화와 선수각 변화가 작다면 운동방정식 (2)의 변수를 분리 하여 식 (1)을 다음의 행렬식으로 근사시킬 수 있다.

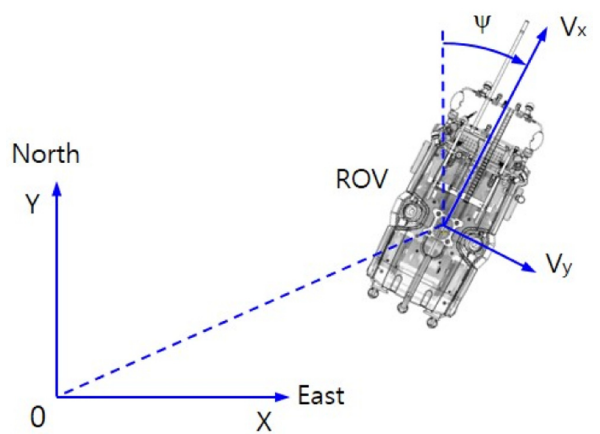

Fig. 1 Relation of vehicle coordinate and global coordinate

$$
x_{k+1}=F_{k} x_{k}+G_{k} a_{k}
$$

여기서, $x_{k}=\left\{X_{k}, Y_{k}, Z_{k}, \psi_{k}, u_{k}, v_{k}, w_{k}, r_{k}\right\}^{T}$,

$$
\begin{aligned}
& a_{k}=\left\{a_{x_{k}}, a_{y_{k}}, a_{z_{k^{\prime}}}, a_{r_{k}}\right\}^{T}, \\
& \boldsymbol{F}_{k}=\left[\begin{array}{cccccccc}
1 & 0 & 0 & 0 & \Delta t \sin \psi_{k} & \Delta t \cos \psi_{k} & 0 & 0 \\
0 & 1 & 0 & 0 & \Delta t \cos \psi_{k}-\Delta t \sin \psi_{k} & 0 & 0 \\
0 & 0 & 1 & 0 & 0 & 0 & \Delta t & 0 \\
0 & 0 & 0 & 1 & 0 & 0 & 0 & \Delta t \\
0 & 0 & 0 & 0 & 1 & 0 & 0 & 0 \\
0 & 0 & 0 & 0 & 0 & 1 & 0 & 0 \\
0 & 0 & 0 & 0 & 0 & 0 & 1 & 0 \\
0 & 0 & 0 & 0 & 0 & 0 & 0 & 1
\end{array}\right]
\end{aligned}
$$

$$
G_{k}=\left[\begin{array}{cccc}
\Delta t^{2} / 2 \sin \psi_{k} & \Delta t^{2} / 2 \cos \psi_{k} & 0 & 0 \\
\Delta t^{2} / 2 \cos \psi_{k}-\Delta t^{2} / 2 \sin \psi_{k} & 0 & 0 \\
0 & 0 & \Delta t^{2} / 2 & 0 \\
0 & 0 & 0 & \Delta t^{2} / 2 \\
\Delta t & 0 & 0 & 0 \\
0 & \Delta t & 0 & 0 \\
0 & 0 & \Delta t & 0 \\
0 & 0 & 0 & \Delta t
\end{array}\right] \text { 이다. }
$$

$\mathrm{ROV}$ 가 변속 또는 방향 전환할 경우에 가속도와 각속도가 발 생한다. 해미래와 같이 대형 ROV는 속도 변화가 작으므로 가속 도 오차가 시스템 모델링 오차 범위 내에 있다고 가정하여, 연 성항을 포함한 오차로 모델링할 수 있다. 따라서 본 논문에서는 가속도를 비연성 정규잡음이라 가정하여 식 (3)을 다음으로 나 타내었다.

$$
\begin{aligned}
& x_{k+1}=F_{k} x_{k}+w_{k} \\
& w_{k} \sim N\left(0, Q_{k}\right)
\end{aligned}
$$

$w_{k}$ 는 평균이 영이고 공분산행렬이 $Q_{k}$ 이다. 위치, 자세, 속도 가 가관측 하다면, 측정오차를 포함하여 다음 식으로 나타낼 수 있으며

$$
\left\{\begin{array}{c}
X \\
Y \\
Z \\
\psi \\
u \\
v \\
w
\end{array}\right\}_{\text {measure }}=\left\{\begin{array}{c}
X+\Delta X \\
Y+\Delta X \\
Z+\Delta Y \\
\psi+\Delta Z \\
u+\Delta u \\
v+\Delta v \\
w+\Delta w
\end{array}\right\}
$$


행렬식으로 나타내면 다음과 같다.

$$
y_{k}=H_{k} x_{k}+v_{k}
$$

여기서, $y_{k}$ 는 측정값 벡터, $H_{k}=\left[I_{7 \times 7} 0_{7 \times 1}\right]$,

$$
\boldsymbol{v}_{k}=\left\{\Delta X_{k}, \Delta Y_{k}, \Delta Z_{k}, \Delta \psi_{k}, \Delta u_{k}, \Delta v_{k}, \Delta w_{k}\right\}^{T}, \boldsymbol{v}_{k} \sim N\left(0, \boldsymbol{R}_{k}\right) .
$$

$v_{k}$ 는 평균이 영, 공분산행렬이 $R_{k}$ 인 측정 정규잡음이라고 가 정한다.

본 논문은 운동모델 식 (4)과 관측모델 식 (6)으로 구성된 항법 방정식에 대하여 칼만필터(Gelb, 1974)를 적용하여 USBL-DVL-선 수각 통합 항법시스템을 구현했다.

\section{2 센서의 신호특성 및 모델링 오차}

USBL-DVL 통합항법 알고리듬은 $10 \mathrm{~Hz}$ 주기로 상태변수를 추 정하고, 새로 얻어진 측정신호가 버퍼에 입력되면 이들을 이용 하여 항법시스템의 상태변수와 오차공분산을 업데이트한다. 해 미래 항법시스템의 측정에 사용되는 센서는 Table 1 과 같다.

통합항법시스템의 측정신호 공분산은 탑재된 센서 특성을 반영하여 다음과 같이 정의했다.

$$
\boldsymbol{R}=\operatorname{diag}\left\{(.003 d)^{2}(.003 d)^{2} 1^{2} .1^{\circ 2} .025^{2} .025^{2} .025^{2}\right\}
$$

여기서 $d$ 는 ROV 탐사지점의 수심이다. Fig. 2는 수심변화에 따른 $\mathrm{USBL}$ 의 위치측정오차를 표준편차로 나타낸 그림이다. $3,000 \mathrm{~m}$ 이하에서 얻어진 데이터는 평균적으로 제조사가 제시한 사양과 유사한 값의 표준편차가 얻어졌다. $3,000 \mathrm{~m}$ 이상의 범위는 데이터 가 많지 않아 특정하기 어려우나 제조사 사양보다 좋은 특성을 보였다. 따라서 본 논문은 $X, Y$ 위치측정의 표준편차를 제조사 사양으로 제시된 $\mathrm{rms}$ 오차값으로 정의했다.

방위각 센서는 정렬오차에 따른 횡 - 종동요 커플링 효과를 고려하여 표준편차를 0.1 도로 정의했고, 심도센서는 수평면 오 프셋 위치에 의한 레버암 효과를 고려하여 표준편차를 $1 \mathrm{~m}$ 로 정 했다. 속도성분은 설치오차 및 횡 - 종동요에 의한 커플링 영향 을 고려하여 표준편차를 $2.5 \mathrm{~cm} / \mathrm{s}$ 로 정했다. 이산시스템에서 측 정오차공분산은 항법시스템의 샘플링 간격 $(\Delta t=0.1 \mathrm{~s})$ 을 고려하

\begin{tabular}{|c|c|c|c|c|}
\hline Sensor & Measurement & Update rate & Precision & Range \\
\hline $\begin{array}{c}\text { Depth } \\
\text { (SBE 49) }\end{array}$ & Z-depth & $\begin{array}{c}10 \mathrm{~Hz} \\
(\sim 16 \mathrm{~Hz})\end{array}$ & $\begin{array}{c}0.1 \% \text { (acc.) } \\
\text { (resol } 0.002 \%)\end{array}$ & $7,000 \mathrm{~m}$ \\
\hline $\begin{array}{l}\text { AHRS } \\
\text { (Octans) }\end{array}$ & $\begin{array}{l}\text { Heading, roll, } \\
\text { pitch }\end{array}$ & $\begin{array}{c}10 \mathrm{~Hz} \\
(\sim 100 \mathrm{~Hz})\end{array}$ & $0.01^{\circ}$ & $500^{\circ} / \mathrm{s}$ \\
\hline $\begin{array}{c}\text { DVL } \\
\text { (RDI } \\
\text { HN300) }\end{array}$ & $\begin{array}{l}\text { u,v,w-velocity } \\
\text { Altitude }\end{array}$ & $<7 \mathrm{~Hz}$ & $\pm 0.4 \% \pm 2 \mathrm{~mm} / \mathrm{s}$ & $\begin{array}{l}0 \sim 10 \mathrm{~m} / \mathrm{s} \\
1 \sim 200 \mathrm{~m}\end{array}$ \\
\hline $\begin{array}{c}\text { USBL } \\
\text { (Posidonia) }\end{array}$ & XYZ-position & $\begin{array}{c}8.33 \mathrm{~s} @ 1,450 \\
\sim 3,100 \mathrm{~m}\end{array}$ & $\begin{array}{l}0.3 \% \mathrm{rms} \text { of } \\
\text { slant range }\end{array}$ & $6,000 \mathrm{~m}$ \\
\hline
\end{tabular}
여 $R_{k}$ 은 $R / \Delta t$ 로 변환된다.

Table 1 Specifications of the sensors for the navigation system

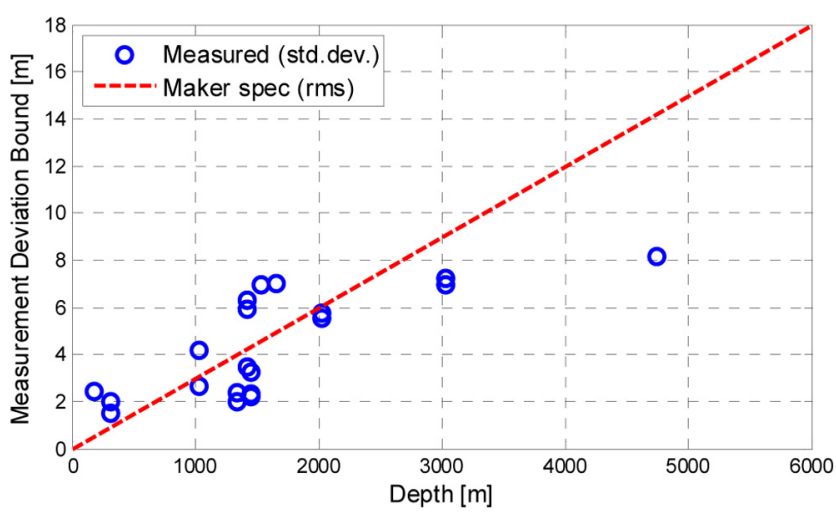

Fig. 2 Characteristics of measurement errors of the USBL Posidonia acoustic position system

USBL은 트랜스폰더 모드 및 리스폰더 모드 선택, 탐사수심, 추 적 물체의 개수에 따라 샘플링 주기를 다르게 세팅해야 한다. 해 미래 시스템은 중계기 해누비 위치를 함께 추적해야 하고 마리아 나 해저화산 탐사(수심 $1,450 \mathrm{~m}, 3,050 \mathrm{~m}$ )에서는 트랜스폰더 모드 를 이용했으므로 샘플링 간격을 8.33초로 고정했다. DVL은 샘플 링 주파수가 최대 $7 \mathrm{~Hz}$ 이며, 측정 거리에 따라 신호취득 추기가 변경되므로 본 논문에서는 측정고도를 $100 \mathrm{~m}$ 이내로 제한했다. 수심은 $16 \mathrm{~Hz}$ 로 얻어지는 $\mathrm{CTD}$ (Conductivity temperature depth) 센 서(SBE 49)의 심도값을 이용했으며, 방위각 정보는 $\mathrm{AHRS}$ 를 이 용하여 최대 $100 \mathrm{~Hz}$ 로 얻어진다.

해미래의 제어주기는 $10 \mathrm{~Hz}$ 이고. 위치측정, 속도측정, 수심 및 방위각 신호는 취득주기가 각각 8.33초, 0.1 또는 0.2 초, 0.1 초, 0.1 초로 다르다. 한편 $\mathrm{DVL}$ 은 신호가 불량하거나 측정범위를 넘 어 신호취득이 불가한 경우가 있으므로, 본 논문에서는 임의 시 간에 측정신호가 업데이트되는 경우의 수를 다음 네 가지로 분 류했다.

(a) 위치, 심도, 방위각, 속도 등 모든 신호 업데이트

(b) 위치, 심도, 방위각 업데이트

(c) 심도, 방위각, 속도 업데이트

(d) 심도와 방위각 신호만 업데이트

본 논문은 측정신호가 업데이트되는 조건에 대응하는 관측행 렬을 다음 식으로 각각 정의하고

$$
\begin{aligned}
& \boldsymbol{H}_{k}=\left[\begin{array}{ll}
I_{7 \times 7} & 0_{7 \times 1}
\end{array}\right] \\
& \boldsymbol{H}_{k}=\left[\begin{array}{lll}
I_{4 \times 4} & 0_{4 \times 4}
\end{array}\right] \\
& \boldsymbol{H}_{k}=\left[\begin{array}{lll}
0_{5 \times 2} & I_{5 \times 5} & 0_{5 \times 1}
\end{array}\right] \\
& \boldsymbol{H}_{k}=\left[\begin{array}{lll}
0_{2 \times 2} & I_{2 \times 2} & 0_{2 \times 4}
\end{array}\right],
\end{aligned}
$$

이를 칼만필터의 업데이트 프로세스(Gelb, 1974)에 적용하여 상태 변수 추정값과 오차공분산을 업데이트했다. 관측행렬은 측정값이 갱신되는 조건에 따라 식 (7a) (7d)가 선택적으로 스위칭 되며, 칼 만 이득이 계산되고 오차공분산이 업데이트된다.

운동방정식 (4)는 수직면운동과 수평면 운동이 독립적이라는 가정 하에 수평면 상에서 운동 모델로 비선형 운동방정식을 선형 
화했고, 추력, 조류력 또는 케이블 외란 등에 의한 가속도가 고려 되지 않았으므로 모델링 오차가 존재한다. 심해에서 운용하는 $\mathrm{ROV}$ 는 운동속도가 1노트 이내에서 추진기를 조정하며, 조류는 통상 0.5 노트 이하 유속의 외란을 받는다. 따라서 가속도 모델링 오차에 의해 잠수정이 가질 수 있는 불확실 운동량을 추정하고, 이에 따라 항법시스템의 변수가 변화할 수 있는 범위를 모델링 오차 공분산으로 정의하여 다음과 같이 선정했다.

$$
\boldsymbol{Q}=\operatorname{diag} 1^{2} 1^{2} 1^{2} 1^{\circ 2} 0.1^{2} 0.1^{2} 0.1^{2}\left(1^{\circ} / \mathrm{s}\right)^{2}
$$

항법시스템의 샘플링 간격을 고려하여 이산시스템의 모델링 오차 공분산 $Q_{k}$ 은 $Q \Delta t$ 로 변환된다.

\section{3. 통합항법시스템의 실해역 데이터 적용}

\subsection{USBL-DVL-선수각 통합항법시스템의 파라미터 튜닝}

USBL-DVL-선수각 통합항법시스템의 성능은 기존에 수행되 었던 심해탐사 데이터에 적용한 시뮬레이션(Re-navigation)을 통 하여 검증했다. 마리아나 해저화산 포케스트와 알키안 탐사에 서 수행된 Dive \#01 \#09 전체 데이터(Lee et al., 2016)에 대해 통합항법시스템을 적용했다. 통합항법시스템은 항법 알고리듬 을 시작하는 순간의 3 차원 위치, 속도, 자세 측정값을 상태변수 의 초기값으로 치환했다.

상태변수의 초기값 오차가 항법시스템에 미치는 영향을 파악 하기 위해 초기 오차공분산 선정에 따른 오차수렴 특성을 검토 했다. 시뮬레이션은 포케스트 Dive \#01에 대해 항법시스템의 초 기 $X$ 위치가 아웃라이어 신호로 세팅되었을 경우를 고려했다. Fig. 3은, USBL의 $X$ 방향 측정에 $\Delta X_{0}=-50 \mathrm{~m}$ 크기의 아웃라이 어가 부가되었을 때, $P_{0}(1,1)$ 과 $P_{0}(2,2)$ 공분산의 표준편차가 1 , $5,10,20,30,50$ 인 경우에 대하여 항법 시률레이션에 의한 $X$ 방 향 궤적을 나타낸다. 오차공분산이 초기 오차보다 크거나 같으 면 USBL 위치가 업데이트 되는 순간 초기오차가 급속히 감소 하나, 오차공분산이 이보다 작으면 작을수록 오차보정에 시간 이 소요된다. 본 논문에서는 $1,500 \mathrm{~m}$ 수심에서 측정한 USBL 신 호가 정상이며 오차가 발생할 수 있는 최대범위로 선택하여 초 기 위치오차공분산을 $5 \sigma(22.5 \mathrm{~m} @ 1,500 \mathrm{~m})$ 로 정했다.

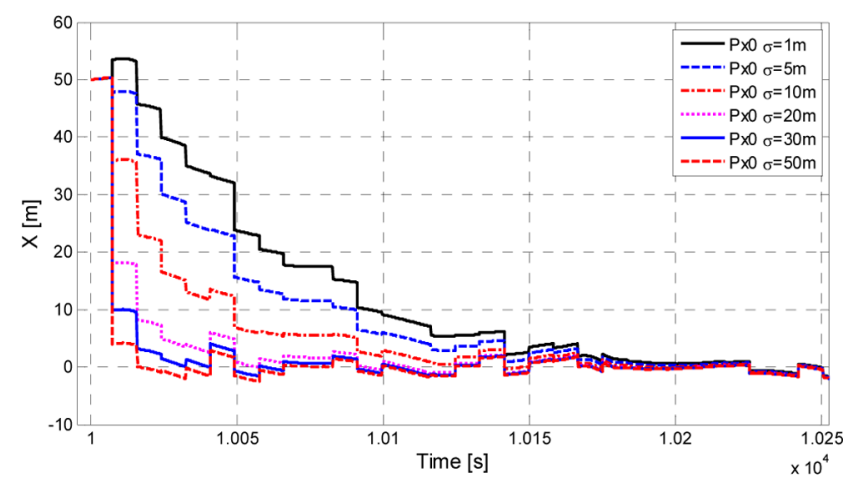

Fig. 3 Effect of the error covariance matrix on the estimated position of USBL-DVL navigation with initial position error $(\triangle \mathrm{X}=-50 \mathrm{~m})$
칼만필터 적용에 필요한 오차공분산 초기값은 다음과 같이 선정됐다.

$$
P_{0}=\operatorname{diag} 22^{2} 22^{2} 1^{2} 1^{\circ 2} 0.05^{2} \quad 0.05^{2} \quad 0.05^{2}
$$

탐사에서 얻어진 DVL 속도 및 USBL 위치 데이터는 정상상 태에서 각각 $0.1 \sim 0.2$ 초 및 8.3초 간격으로 신호가 취득됐다. 위 치 및 속도 측정에 아웃라이어가 발생하거나 이전 샘플시간에 취득된 신호와 동일한 신호가 얻어지는 경우에, 통합항법시스 템은 측정신호가 새롭게 갱신되지 않을 것으로 판단하여 칼만 필터의 업데이트 루틴을 수행하지 않고 상태변수를 추정한다. Fig. 4(a)는 Dive \#1에 대한 DVL과 USBL의 신호가 갱신될 때마 다의 시간간격을 로그 스케일로 나타낸 것으로, 횡축은 DVL과 USBL 각각의 취득신호 갱신 순번을, 종축은 취득신호의 시간간 격을 나타낸다. Fig. 4(b)는 샘플시간간격의 빈도수를 로그-로그 스케일로 나나낸 히스토그램이다. USBL은 갱신 데이터 중에서 약 $7.5 \%$ 가 8.3 초 주기보다 긴 시간간격을 갖는 데이터가 얻어졌 다. USBL 갱신 데이터 시간간격은 2 배수, 3 배수, 4 배수이며, 이 중에는 아웃라이어 발생으로 제거된 신호와 이전 위치와 동일 한 위치 측정에 의해 신호갱신이 무시된 영향으로 판단된다. 반 면에 DVL은 절반 이상의 데이터가 0.2 초 주기보다 긴 신호갱신
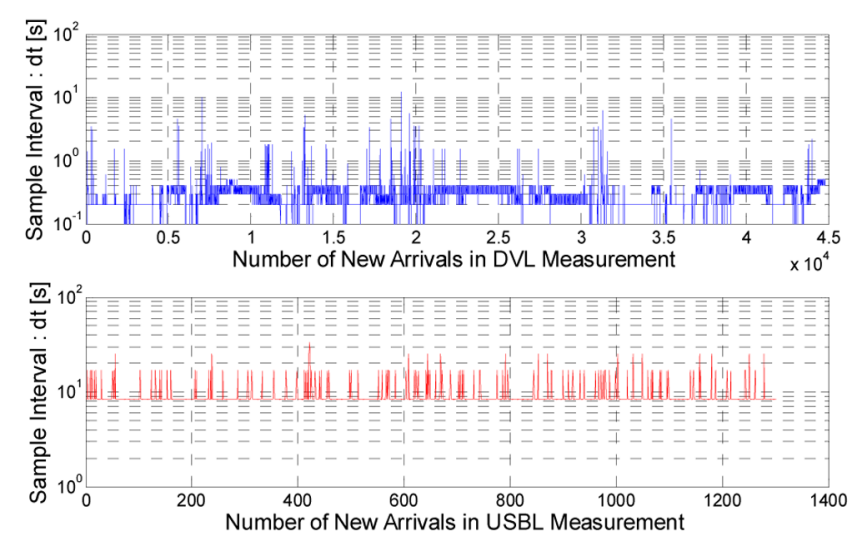

(a) Sample intervals of DVL and USBL measurements
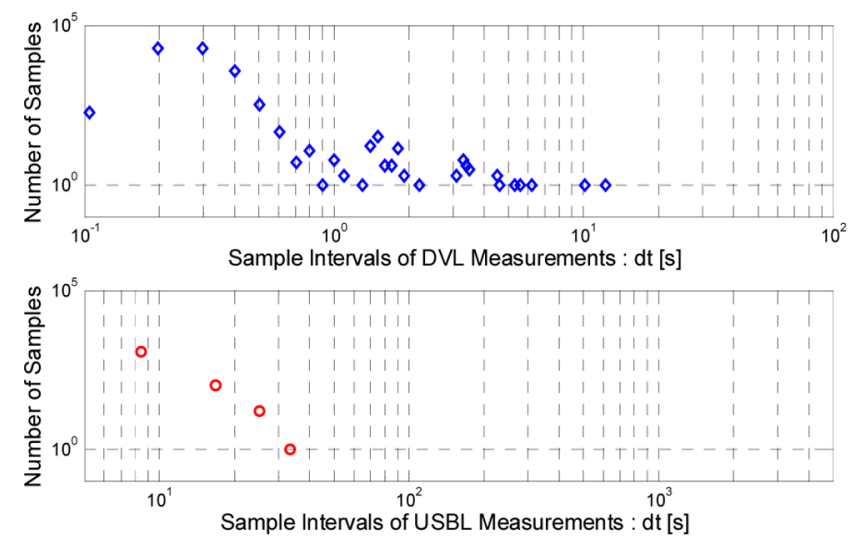

(b) Histogram of the sample intervals of DVL and USBL measurements

Fig. 4 Sample interval of DVL and USBL measurements of Dive $\# 1$ at Forecast subsea volcano. 
주기를 갖는 속도 데이터가 얻어졌고, 1 초, 길게는 10 초 이상 유효한 속도신호가 측정되지 않는 경우도 있었다. DVL은 해저 면 반사신호를 이용해 속도를 계측하는데, 해저화산 지역은 지 형이 불규칙하고 경사가 심해 해저면 반사신호의 수신 불량이 자주 발생한 것으로 판단된다.

속도센서로 사용된 RDI $\mathrm{WHN} 300$ 은 고도 $1 \mathrm{~m}$ 부터 $200 \mathrm{~m}$ 까지 측정이 가능하다. 해미래가 해저면에 착지했을 경우는 고도가 $1 \mathrm{~m}$ 이내이므로 속도계측이 불가능했다. 해저화산의 급경사 지 역에서는 잠수정이 해저면으로부터 $1.5 \sim 2 \mathrm{~m}$ 고도를 유지하며 운 항하거나 경사면에 기대어 작업할 경우에도 속도신호 불량이 빈번하게 발생했다. 경사지역에서는 DVL의 네 개 음향빔 중에 서 2개 이상의 빔은 근접거리에서 반사신호를 수신하고, 나머지 2개 음향빔은 원거리 신호를 수신하게 되므로 나타나는 현상으 로 추정되며, 특히 잠수정의 종·횡동요 및 방위각 변화에 민감 하게 영향을 받아 발생하는 현상으로 사료된다. 또한 해미래 $\mathrm{ROV}$ 가 정지해 있거나 등속으로 이동하여 속도변화가 거의 없 는 경우는 이전과 동일한 속도신호가 얻어질 수 있으므로 신규 신호갱신이 없는 현상을 포함한다.

항법시스템 운용 중에 USBL 신호에 아웃라이어를 포함하는 경 우에 이 신호가 항법시스템에 미치는 영향을 검토했다. Fig. 5는 Dive \#01 탐사 중 10,000 초에 위치오차 $\Delta X=-40 \mathrm{~m}$ 를 포함하는 아 웃라이어가 발생한 상황을 가정하여 시뮬레이션된 통합항법시스 템의 X-Y 추정변수 궤적을 나타낸다. 위치 모델링오차공분산 $Q$ 의 영향을 파악하기 위하여 위치모델링 오차의 표준편차를 0.1 5.0 사이에서 단계적으로 증가하며 시뮬레이션을 수행했다.

모델링 오차공분산이 작으면 아웃라이어 영향을 작게 받으나, 다른 정상적인 측정값이 항법시스템의 상태변수 및 오차공분산 업데이트에 미치는 영향이 작아진다. 이 경우에는 정상적인 USBL 측정에 의한 위치보정이 미미하게 되고, 따라서 위치추정 에 시간지연이 발생하게 되어 왜곡된 경로를 추정하게 된다. 한 편 모델링 오차 공분산이 크면 아웃라이어 영향을 크게 받을 뿐 만 아니라 노이즈가 있는 USBL 신호를 그대로 추종하는 경향이 커진다. 점프가 있는 USBL 신호추종을 최소화하며 아웃라이어 영향을 적게 받는 $\sigma$ 값으로 $0.5 \sim 1.0 \mathrm{~m}$ 가 적절했다. 속도신호가 정

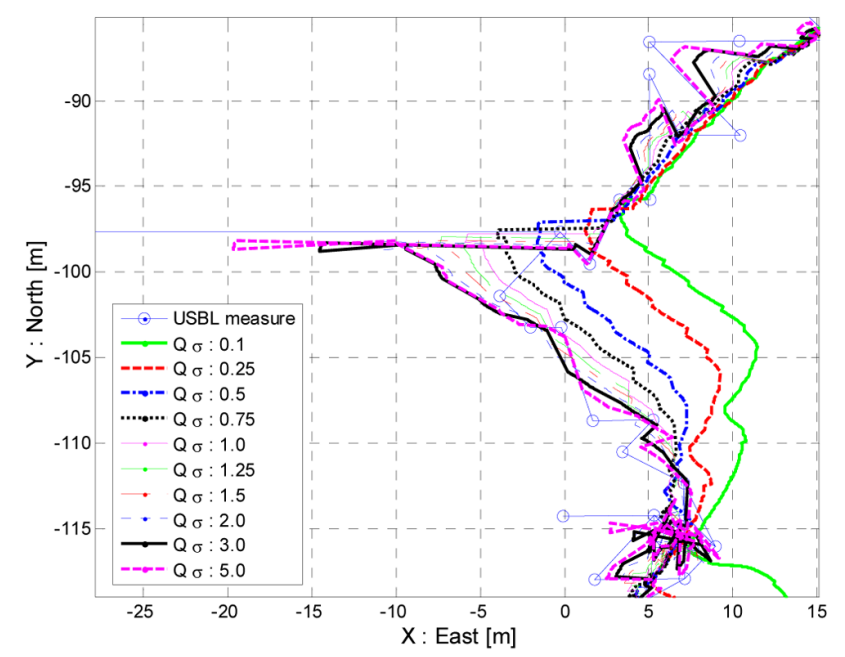

Fig. 5 Effect of outlier $(\Delta X=-40 m)$ on the navigation according to the variation of the system error covariance
상인 경우는 작은 값이 유리하고, 비정상인 경우는 큰 값이 유리 했다. 본 논문은 위치 모델링오차 표준편차 $\sigma$ 를 $1 \mathrm{~m}$ 로 정했다.

\section{2 해저화산 탐사 데이터에 통합항법시스템 적용}

앞 절에서 설계된 USBL-DVL-선수각 통합항법시스템을 이용하 여 마리아나 포케스트 해저화산 탐사 데이터에 적용했다. Fig. 6은 Dive \#01 데이터를 이용하여 USBL-DVL 통합항법을 실시한 결과를 나타낸다. 항법시스템은 잠수정이 해저탐사를 수행한 [10 12,000]초 전체 시간 구간에 대해 적용됐다. Dive \#01은 해저화산 정상부근의 3 개 열수공을 조사하고 주변을 이동하며 해저환경을 관측했다. 통

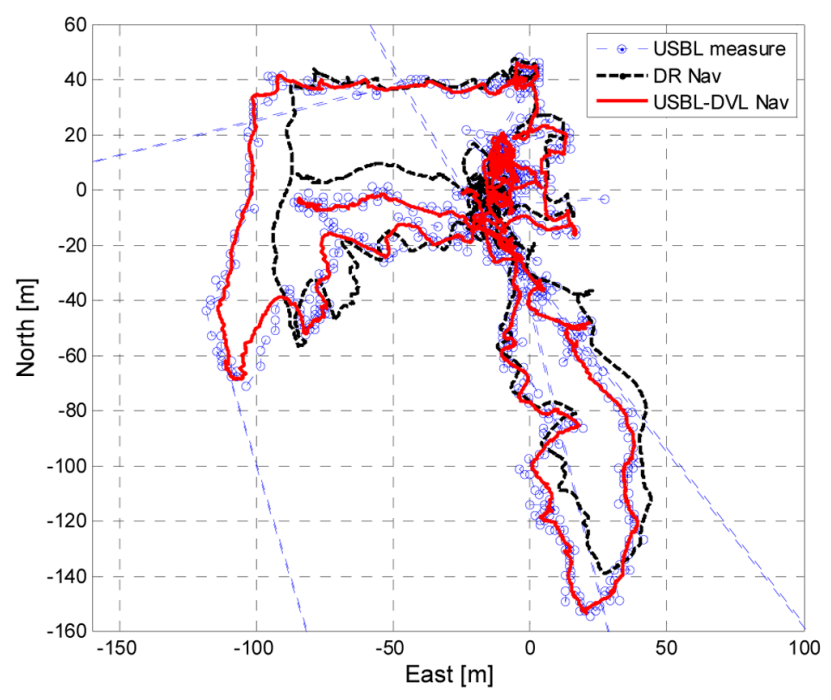

(a) X-Y plane trajectories
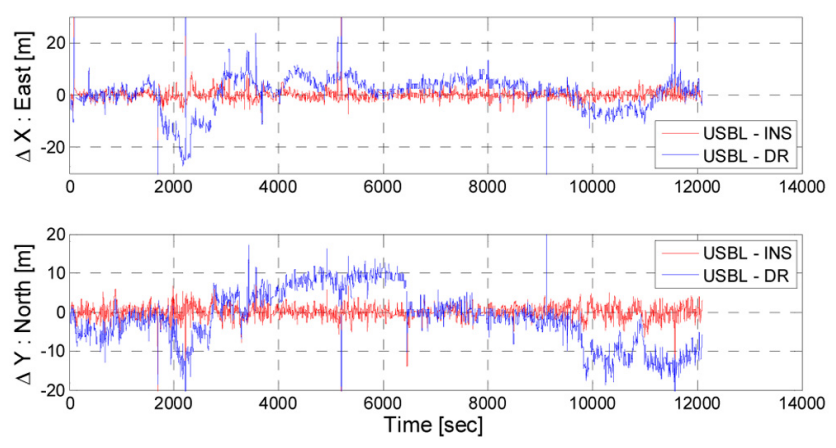

(b) Difference between USBL and INS/DR position estimates
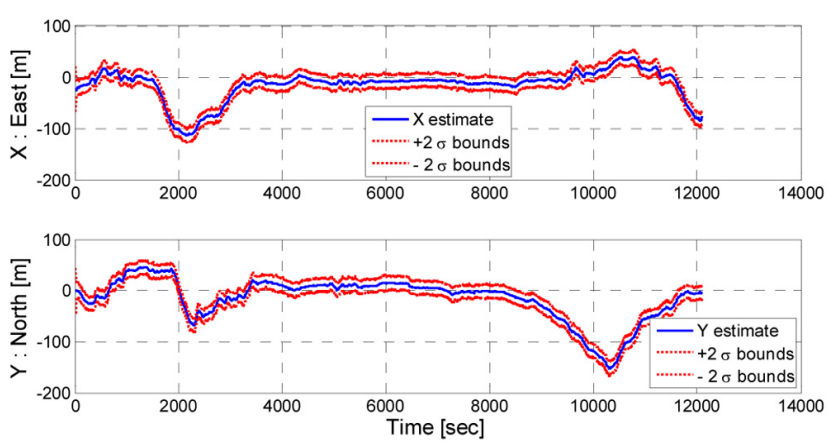

(c) Error bound of the estimated position $(2 \sigma)$

Fig. 6 Re-navigation with USBL-DVL navigation system for Dive \#01 conducted at Forecast subsea volcano 


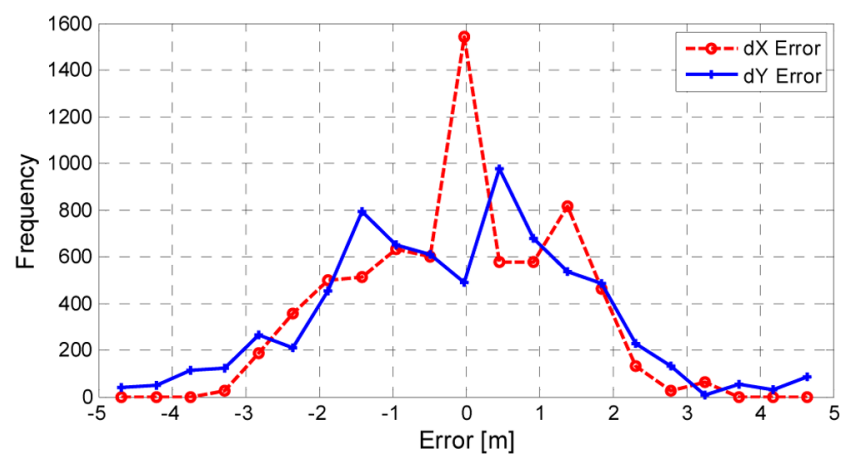

Fig. 7 Histogram of the error of USBL measurement and USBL-DVL navigation for Dive \#01 survey

합항법시스템은 아웃라이어를 포한한 USBL 측정신호 원본 데이터 를 이용했으며, USBL 아웃라이어(발생 시간 : $92,1,694,2,222,5,210$, $9,126,11,584$ 초) 신호는 필터링을 통해 제거하여 신호 업데이트에 사용하지 않았다. 아웃라이어 판정 기준은 다음 절에서 상세히 논의 했다. 속도신호는 고도신호가 영으로 관측되는 순간의 속도를 불량 신호로 판정하여 신호갱신에 이용하지 않았다.

Fig. 6(a)는 해미래가 이동한 수평면 궤적을 나타내며, USBL 측 정위치(점선 원형 마크), 통합항법 추정위치(실선), DR 항법 추정 위치(파선)을 동시에 표시되었다. Fig. 6(b)는 USBL 측정위치에 대 한 통합항법과 DR 항법의 위치추정 차이를 나타낸다. Fig. 6(c)는 통합항법시스템의 위치추정 상태변수의 시계열 데이터와 함께 위 치추정 오차 범위 $( \pm 2 \sigma)$ 를 나타내며, 전 구간에 걸쳐 약 $20 \mathrm{~m}$ 반경 을 균일하게 유지했다. 항법성능 비교를 위하여 탐사현장에서 사 용했던 DR항법에 의한 위치추적 궤적(검은 실선)을 함께 나타냈 다. DR 항법 궤적은 USBL 측정과 $10 \mathrm{~m}$ 이상 오차가 발생하면, 파 일럿의 판단 하에, DR 항법 추정위치를 USBL위치로 리셋하여 탐 사가 수행되었다. Dive \#01에서는 DR항법과 USBL 측정사이의 위 치오차가 2,200 초 근처에서 최대 $30 \mathrm{~m}$ 오차가 발생했으며, 6,450 초 에 DR항법의 위치를 USBL로 한 차례 리셋했다. 이후에도 DR 항 법의 위치오차는 최대 $17 \mathrm{~m}$ 범위에서 변동했다. 반면에 통항합법 은 USBL과의 위치오차가, 2,340 초 근방에서 $8 \mathrm{~m}$ 발생한 것을 제외 하면, 해저탐사 전 구간에서 약 $2 \mathrm{~m}$ 표준편차를 가지며 안정적으 로 위치를 추정했다. Fig. 7은 USBL과 통합항법 추정위치의 오차 (두 신호의 차이) 히스토그램을 나타낸다. 오차의 크기는 정규분 포로 근사시킬 수 있는 분포를 가졌으며, 평균 $0.173 \mathrm{~m}$, 표준편차 $2.17 \mathrm{~m}$ 로 통합항법시스템이 안정하게 작동한 결과를 보였다.

Fig. 8은 잠수정이 해저면에 착지해 해저퇴적물포집장치 회수 작업을 수행한 Dive \#07에 대한 항법시스템 적용 결과를 나타낸 결과로서 그림 세부항목은 Fig. 6과 동일하다. 우측 신호밀집지역 이 잠수정의 포집장치 회수작업 위치를 나타낸다. USBL 아웃라 이어가 2회 발생(발생시간: 7,489초, 7,725초)했고, 7,375 7,455초 사이에 USBL 블랙아웃이 발생했다. DR항법은 6830.6초에 시작 되었으며, 노이즈가 섞인 USBL 위치가 초기값으로 지정되어 오 프셋을 가진 궤적을 보였으며, 7,238초에 위치를 리셋하여 오프 셋이 제거된 상태를 볼 수 있다. USBL-DVL 통합항법은 전 구간 안정적으로 위치를 추정했으며, 해저 착지 시 유효 DVL 신호가 없는 구간(7,900 8,650초)에서도 USBL 신호를 이용하여 주기적 으로 위치를 보정함으로써 안정적인 항법을 구현함을 알 수 있

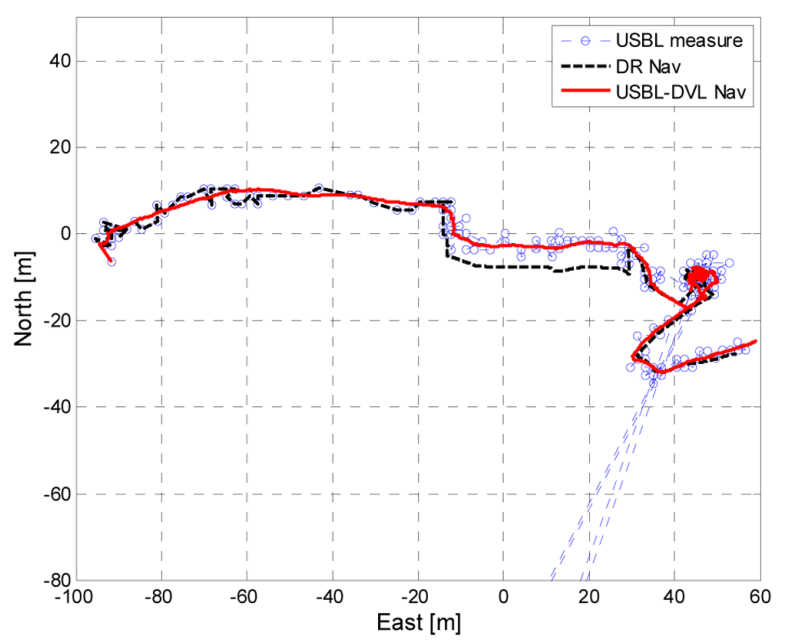

(a) X-Y plane trajectories
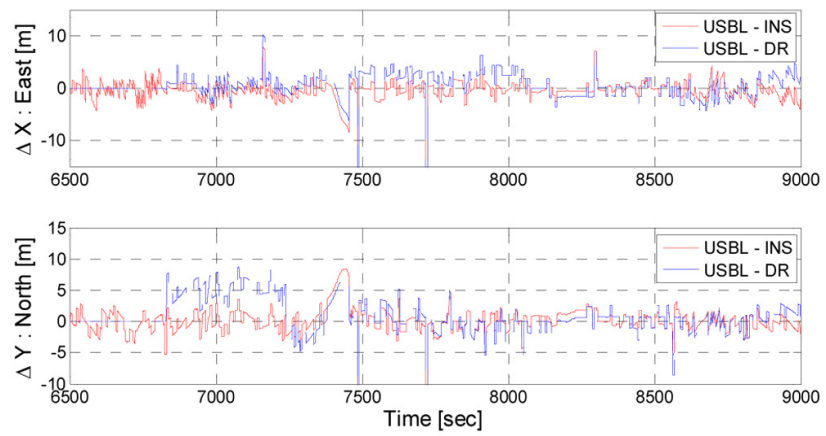

(b) Difference between USBL and INS/DR position estimates
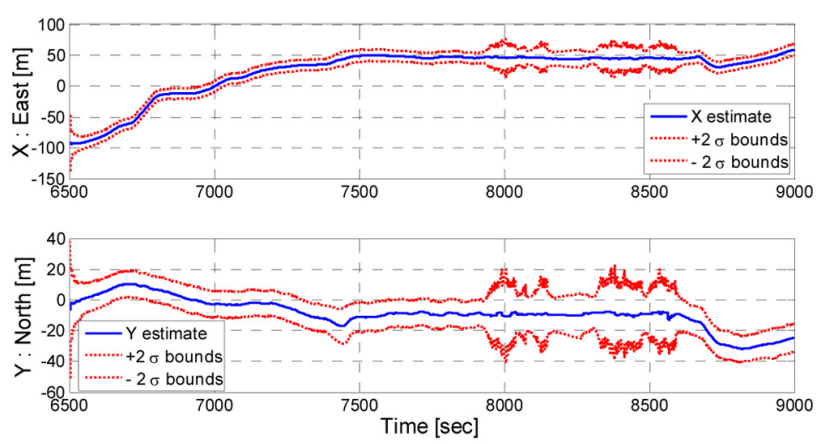

(c) Error bound of the estimated position $(2 \sigma)$

Fig. 8 Re-navigation with USBL-DVL navigation system for Dive \#07 conducted at Forecast subsea volcano

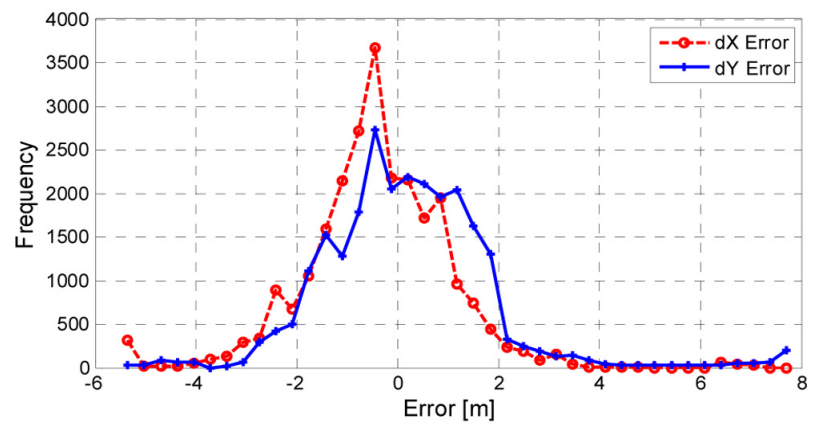

Fig. 9 Histogram of the error of USBL measurement and USBL-DVL navigation for Dive \#07 survey 
다. Fig. 8(c)는 추정위치와 오차공분산의 $2 \sigma$ 경계를 도식한 그림 이며, 속도신호 입력이 없는 구간에서 오차공분산이 USBL 보정 이 이루어지면서 증감하며 변동하는 결과를 보였다. Fig. 9는 USBL과 통합항법 위치 추정의 오차 히스토그램을 나타내며, 오 차는 유사 정규분포를 보이며, 평균 $0.453 \mathrm{~m}$, 표준편차 $2.27 \mathrm{~m}$ 로 Dive \#01과 유사한 결과를 보였다.

\section{3 블랙아웃을 고려한 아웃라이어 제거법}

2016년 4월 2일 수행된 해미래의 알키안 흑연열수분출공 탐 사Dive \#9에서 잠수정이 해저에서 탐사를 시작한 직후부터 USBL 위치측정이 장시간 얻어지지 않는 블랙아웃 현상이 발생 했다. 이 해역의 수심은 $3,000 ~ 3,100 \mathrm{~m}$ 이며, USBL의 샘플 취득 간격은 수심이 $1,450 \mathrm{~m}$ 포케스트 탐사와 동일하게 8.33 초로 정했 다. 트랜스폰더 모드로 운용되는 USBL의 샘플링 간격을 길게 조정하고 커넥션을 바꿔보는 등 여러 가지 조치를 취했으나, $\mathrm{USBL}$ 측위불량 원인은 정확히 파악되지 않았다. Fig. 10에서 파 란 점선으로 표시된 것이 USBL 측정위치를 나타낸다. 블랙아웃 이 발생한 시간 구간을 편의상 (1) $[15,10015,960]$ 초, (2) $[15,960$ $16,832]$ 초, (3) $[16,83218,908]$ 초 세 구간으로 구분했다. 블랙아웃 구간 (1)과 구간 (2)는 간헐적인 유효 신호와 1회 또는 7회의 아 웃라이어가 각각 포함되었다. 블랙아웃 구간 (3)은 2,076초 동안 아무런 신호가 수신되지 않았다. 다행스럽게도 18,908 초 이후에 는 USBL 신호가 다시 안정적으로 얻어졌다.

한편, Dive \#9에서 얻어진 DVL 속도 신호는 지형변화가 심한 지역적 특성으로 인하여 계측상태가 양호하지 않았다. Fig. 11은 측정된 속도성분 $V_{x}, V_{y}, V_{z}$ 를 나타낸다. 그림에서 $\mathrm{DVL}$ 로 계측 된 고도가 영(Zero)으로 얻어지는 경우에는 속도신호가 붉은 점 으로 표시되었다. DVL 신호불량은 블랙스모커를 수색하며 이동 중인 17,000 초부터 간헐적으로 발생했으며, 블랙스모커 근처에 다다른 시간 19,035 초 이후에 집중적으로 발생했다. 붉은 점으로 표시된 시점의 속도는 신뢰할 수 없으므로, USBL-DVL 통합항법 시스템은 고도신호가 영인 상태에서는 계측된 속도를 신뢰하지 않고 DVL 센서의 데이터 버퍼에 저장된 이전 속도값을 유지하 는 방법을 적용했다.

Fig. 12는 Fig. 4와 동일한 방법으로 Dive \#9에 대해 DVL과 USBL의 신호갱신 주기를 나타낸 그림이다. 앞서 언급한 것과 같 이, DVL 속도 및 USBL 위치 데이터는 정상상태에서 각각 0.1
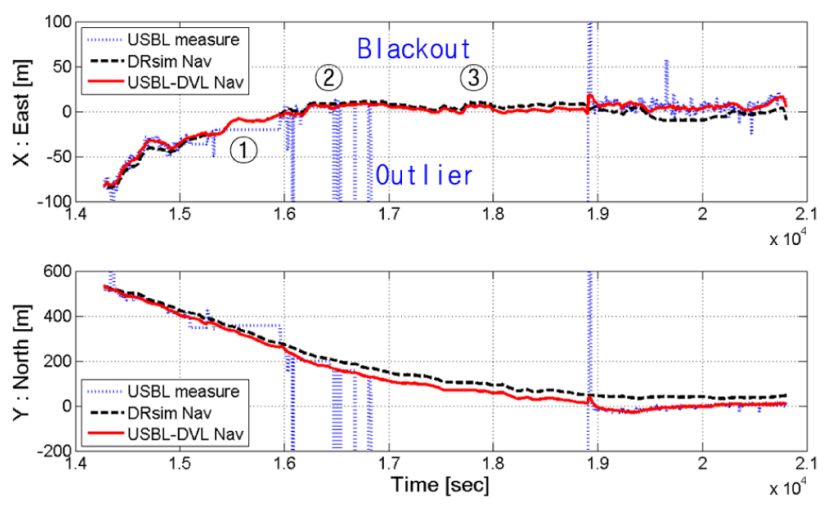

Fig. 10 USBL outliers and blackouts of Dive \#09 at the Archaean subsea volcano.

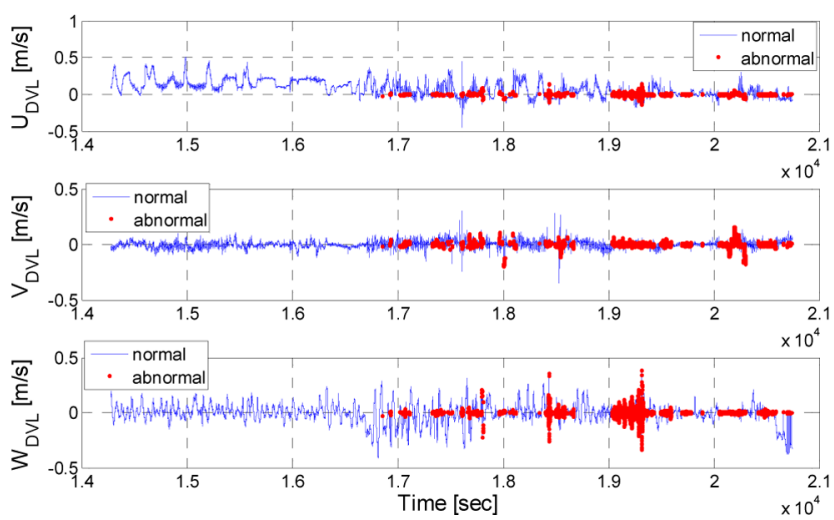

Fig. 11 Velocities acquired with DVL including abnormal measurements of which altitude is zero in Dive \#09 at Archaean subsea volcano.
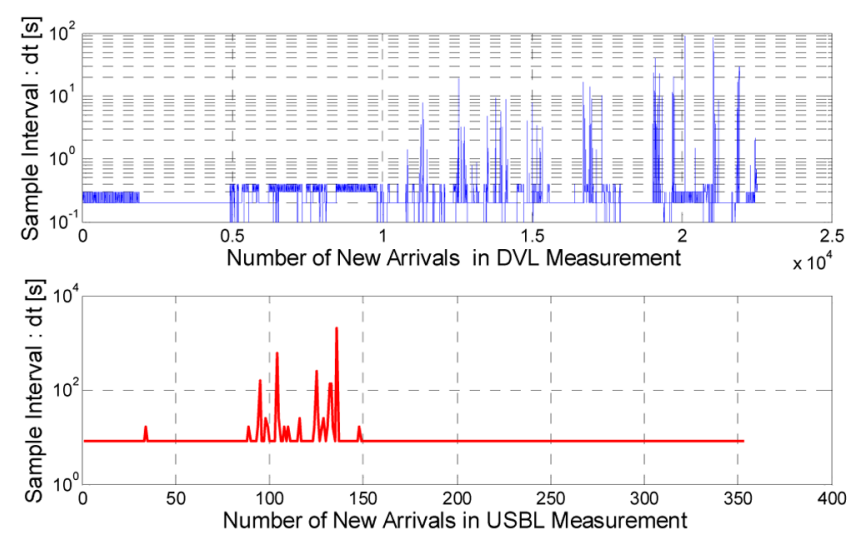

(a) Sample intervals of DVL and USBL measurements
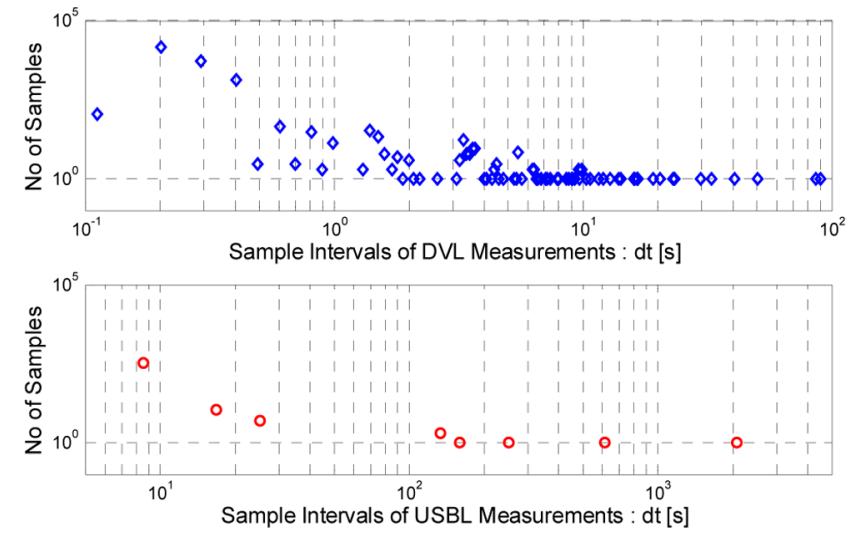

(b) Histogram of the sample intervals of DVL and USBL measurements

Fig. 12 Sample interval of DVL and USBL measurements of Dive $\# 9$ at Archaean subsea volcano.

0.2 초 및 8.33 초 간격으로 신호가 취득되어야 한다. Fig. 12를 Fig. 4 와 비교하면, Dive \#1과 달리 Dive \#9은 DVL 신호에 다양한 크기 의 블랙아웃(최대 90초)이 빈번히 발생했음을 알 수 있다. 한편, USBL은 항해 중간에 100 초 이상 신호가 수신되지 않은 블랙아웃 이 6회 발생했고, 길게는 600초, 최장 2076초 동안 블랙아웃 상태 가 지속되었다. 블랙아웃이 발생한 시간 동안에 잠수정은 이동하 
고 있으므로, USBL 위치측정에 블랙아웃이 발생한 후 다시 신호 를 수신하는 경우에는 잠수정의 위치 이동을 고려하여 수신된 $\mathrm{USBL}$ 측정이 유효한 신호인지 아닌지를 판단해야 한다. 본 논문 은, 운항중인 잠수정의 위치측정에 블랙아웃이 발생할 경우, 블랙 아웃 시간에 대응하는 가변 아웃라이어 판단 제거법을 제안했다.

본 논문은 다음 두 조건을 충족하면 USBL 위치측정이 아웃라 이어인 것으로 판단했다. (1) $k$ 시간 스텝에서 측정한 USBL의 $X$, $Y$ 위치 $\left(X_{k U S B L}, Y_{k U S B L}\right)$ 와 아웃라이어가 발생하지 않았던 이전 시간스텝에서 측정한 $\mathrm{USBL}$ 의 $X, Y$ 위치 $\left(X_{p U S B L}, Y_{p U S B L}\right)$ 차이가 $5 \sigma$ 이상이고, (2) USBL 위치측정 신호가 얻어진 순간에 항법시스 템에서 얻어지는 추정위치 $\left(\widehat{X}_{k}, \widehat{Y}_{k}\right)$ 와 USBL 측정위치의 오차반경 이 아웃라이어 임계값(TOD, Threshold of Outlier Decision)을 초과 하는 경우에 아웃라이어가 발생한 것으로 판정했다.

$$
\begin{aligned}
& |\Delta X|>K_{1},|\Delta Y|>K_{1} \\
& \Delta R_{\text {estimate }}>\text { TOD }
\end{aligned}
$$

여기서 $\Delta X=X_{k U S B L}-X_{p U S B L}, \Delta Y=Y_{k U S B L}-Y_{p U S B L}$,

$$
\begin{aligned}
& K_{1}=\text { 상수, } \\
& \Delta R_{\text {estimate }}=\sqrt{\left(\widehat{X}_{k}-X_{k U B S L}\right)^{2}+\left(\widehat{Y}_{k}-Y_{k U B S L}\right)^{2}} \text { 이다. }
\end{aligned}
$$

$\mathrm{TOD}$ 는 $k$ 시간스텝에서 $X-Y$ 평면 오차공분산행렬 표준편차 의 $\alpha$ 배수 값과 $K_{2}$ 중에서 큰 값을 취하며

$$
\mathrm{TOD}=\max \left(K_{2}, \alpha \sqrt{P_{k}(1,1)+P_{k}(2,2)}\right)
$$

$K_{2}$ 는 상수, $P_{k}(1,1)$ 과 $P_{k}(2,2)$ 는 $k$ 시간 스텝에서의 $X, Y$ 위치 오차공분산이고, $\alpha$ 는 가중치이다.

Fig. 2 에서 수심 $1,450 \mathrm{~m}$ 의 USBL 측정오차와 알키안 $3,042 \mathrm{~m}$ 수 심의 USBL 측정오차가 유사한 값을 보이므로, 본 논문에서 $K_{1}$ 과 $K_{2}$ 는 마리아나 열수탐사 Dive \#1 \#9 데이터에 동일한 값을 적 용했다. 본 논문에서 $K_{1}$ 은 $22.5 \mathrm{~m}(5 \sigma @ 1,500 \mathrm{~m}) K_{2}$ 는 $18 \mathrm{~m}(4 \sigma$ $(1,500 \mathrm{~m}), \alpha$ 는 1.0 이다. 이 방법은 블랙아웃이 발생하지 않은 경 우에는 아웃라이어 판정 임계값이 작은 값을 갖고, 블랙아웃이 발생하면 블랙아웃 지속시간에 따라 위치오차공분산이 증가하면 서 아웃라이어 판정 임계값이 증가한다.

\section{4 블랙아웃이 존재하는 데이터에 통합항법시스템 적용}

USBL 신호의 블랙아웃이 존재하는 알키안 열수분출공 탐사 Dive \#9에 대하여 통합항법시스템을 적용했다. Fig. 13(a)는 통 합항법에 의한 위치추정 결과를 나타낸다. 항법파라미터는 Dive $\# 1$ 과 \#7에 적용한 값과 동일하게 취했으며, 가변 아웃라이어 제 거법 식 (8), (9), (10)을 이용해서 아웃라이어를 제거했다.

통합항법시스템은 블랙아웃 구간 (1)과 (2)에서 간헐적으로 유 효한 USBL 위치측정을 이용하여 아웃라이어를 제거하며 $6 \mathrm{~m}$ 오 차범위 내에서 위치를 추정했다. 통합항법시스템은 블랙아웃 구 간 (3)이 끝나고 USBL 신호가 다시 수신되는 순간에 정상신호로 판정된 USBL 측정값을 이용하여 추정위치가 보정되었다. 통합

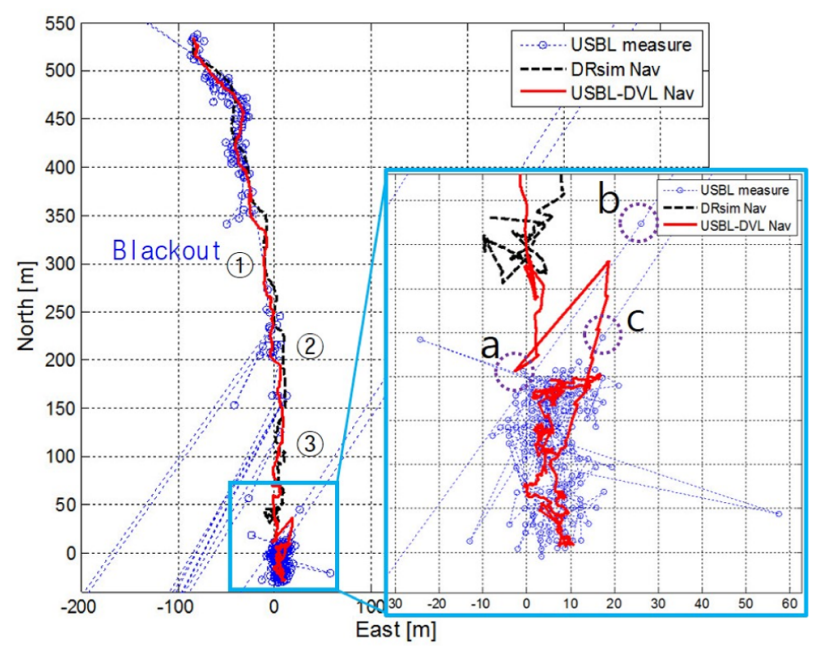

(a) X-Y plane trajectories
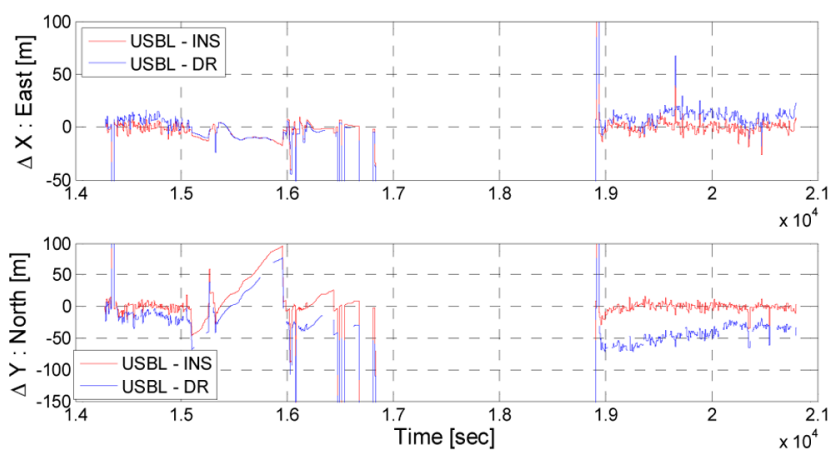

(b) Difference between USBL and INS/DR position estimates
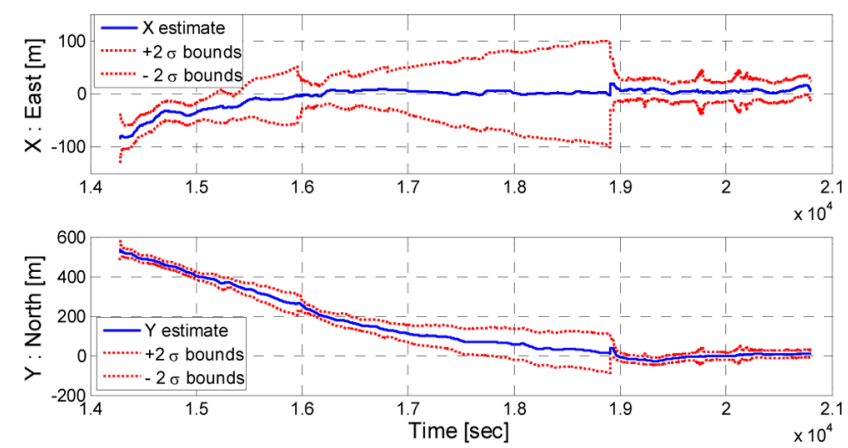

(c) Error bound of the estimated position $(2 \sigma)$

Fig. 13 Re-navigation with USBL-DVL navigation system for Dive \#09 conducted at Archaean subsea volcano.

항법 추정위치가 $\mathrm{a}$ 인 시각에서, USBL 신호 $\mathrm{b}$ 가 수신되었을 때, 추정위치 $\mathrm{a}$ 의 $\left(\widehat{X}_{k}, \widehat{Y}_{k}\right)=(-2.75,11.22)$,

측정위치 $\mathrm{b}$ 의 $\left(X_{k U S B L}, Y_{k U S B L}\right)=(26.06,44.81)$,

$P_{k}(1,1)=P_{k}(2,2)=49.12^{2}$ 이므로, $\Delta R_{\text {estimate }}=44.25, \mathrm{TOD}=69.46$ 이다.

따라서 USBL 측정신호 $\mathrm{b}$ 는 정상신호로 판정되고 통합항법시 스템은 이 신호를 이용해 상태변수 추정과 오차공분산을 업데 이트한다. 만약 $\alpha$ 가 0.5 로 선정된다면, $\mathrm{TOD}$ 는 34.73 이 되어 측 
정위치 $\mathrm{b}$ 는 아웃라이어로 취급되며, 항법시스템은 다음 시각에 얻어지는 USBL의 유효 측정위치 $\mathrm{c}$ 에 의해 추정위치와 오차공 분산의 업데이트가 이루어지게 된다. 오랜 시간 블랙아웃 이후 에는 아웃라이어 범위를 크게 정하는 것이 안전할 것임으로, 본 논문은 $\alpha$ 를 1.0 으로 선택했다.

Fig. 13(b)는 USBL 측정값과 통합항법 추정위치의 차이 및 DVL 항법 추정위치 차이를 나타낸 그림이다. Fig. 13(c)는 위치 추정변수와 오차범위 $(2 \sigma)$ 를 나타내는 그림으로서, USBL 블랙아 웃 발생 시 오차범위가 증가한다. 블랙아웃 구간(3)에서 오차범 위는 약 $100 \mathrm{~m}$ 까지 증가했다. 18,908 초 이후, 정상상태의 USBL 신호가 수신되면서, 추정위치는 USBL 신호가 수신될 때마다 업 데이트되어 USBL의 평균위치로 수렴하는 것을 알 수 있다.

따라서 위치추정 오차공분산을 이용한 아웃라이어 필터링 기 법을 이용함으로써, 통합항법시스템은 장시간 USBL 신호가 블 랙아웃인 상황에서 DVL과 선수각 정보를 이용하여 위치를 추 정할 수 있다. USBL 신호가 정상으로 복귀되면 이를 이용하여 추정위치를 안정적으로 업데이트하며 추정오차가 수렴함을 시 뮬레이션을 통해 확인했다.

\section{4. 결 론}

본 논문은 USBL과 DVL 신호 및 선수각 정보를 융합한 통합 항법시스템을 제안했으며, 심해탐사 데이터를 이용하여 항법시 스템의 유효성을 검증했다. 통합항법시스템은 칼만필터를 기반 으로 항법 알고리듬을 구성했고, 상이한 신호주기를 갖는 항법 센서들의 비동기 측정신호를 이용하여 상태변수 및 오차공분산 을 보정했다. USBL과 DVL 신호특성을 고려하여 항법시스템의 초기오차공분산, 모델링 오차공분산 및 관측오차공분산을 선정 했다. 실제 탐사데이터를 이용하여 초기오차, 아웃라이어에 대 한 민감도를 분석했다. USBL 신호의 블랙아웃 상황에 대처할 수 있는 아웃라이어 제거법을 개발했으며, 장시간 블랙아웃이 존재하는 알키안 탐사 데이터에 적용하여 안정적으로 작동함을 확인했다. 개발된 통합항법시스템을 이용함으로 향후에는 보다 안정적인 심해탐사가 구현될 것으로 기대된다.

\section{후기}

본 논문은 해양수산부의 국가연구개발사업인 “심해 유무인 잠 수정 기술개발 및 운용인프라 구축 - 기술개발” 및 선박해양플랜 트연구소의 주요사업인 “극지 환경을 고려한 수중음향기반 위치 추정 및 해상 항법 기초 기술 연구”에 의해 수행되었습니다 (PMS3470, PES9230).

\section{References}

Gelb, A., 1974. Applied Optimal Estimation. MIT Press, Cambridge.
Kang, H., Hong, S., Sur, J., Kim, J., 2017. Design of GPS-aided Dead Reckoning Algorithm of AUV using Extended Kalman Filter. Journal of Korean Society of Ocean Engineers, 31(1), 28-35.

Kinsey, J.C. and Whitcomb, J.J., 2004. Preliminary Field Experience with DVLNAV Integrated Navigation System for Oceanographic Submersibles. Control Engineering Practice, 12, 1541-1549.

Lee, P., Jun, B., Baek, H., Kim, B., Shim, H., Park, J., Yoo, S., Jeong, W., Baek, S. and Kim, W., 2016. Explorations of Hydrothermal Vents in the Southern Mariana Arc Submarine Volcanoes using the ROV Hemire. Journal of Korean Society of Ocean Engineers, 30(5), 389-399.

Lee, P., Jun, B., Kim, K., Lee, J., Aoki, T. and Hyakudome, T., 2007. Simulation of an Inertial Acoustic Navigation System with Range Aiding for an Autonomous Underwater Vehicle. Journal of Oceanic Engineering, 32(2), 392-345.

Lee, P., Kim, B., Shim, H., Baek, H., Baek, S., Park, J. and Jun B., 2015. An Underwater Navigation System for an ROV Integrated with Inertial Sensors and USBL Position Measurements. Proc. of the KSOE 2015 Autumn Conf., Daejeon, 450-453.

Lee, P., Shim, H., Baek, H., Kim, B., Park, J., Jun, B. and Yoo, S., 2017. A Navigation System of a Deep-sea ROV Fusing USBL and DVL Measurements. Proc. of the KSOE Session of the KAOSTS Conf., April 19-20, Bexco.

Miller, P.A., Farrel, J.A., Zhao, Y. and Djapic, V., 2010. Autonomous Underwater Vehicle Navigation. Journal of Oceanic Engineering, 35(3), 663-678.

Ribas, D., Ridao, P., Mallios, A. and Palomeras, N., 2012. Delayed State Information Filter for USBL-Aided AUV Navigation. Int. Conf. on Robotics \& Automation, 4898-4903, May 14-18, Saint Paul.

Ridao, P., Ribas, D., Hernàndez, E. and Rusu, A., 2011. USBL/ DVL Navigation Through Delayed Position Fixes. Int. Conf. on Robotics \& Automation, May 9-13, Shanghai.

Rigby, P., Pizarro, O. and Williams, S.B., 2006. Towards GeoReferenced AUV Navigation Through Fusion of USBL and DVL Measurements. Oceans Conference, Boston.

Sane-Muntadas, A., Brekke, E.F., Hegrenæs, Ø. and Pettersen, K.Y., 2015. Navigation and Probability for Successful AUV Docking Using USBL. IFAC-PapersOnLine 48-16, 204-209.

Vasilijevic, A., Borovic, B. and Vukic, Z., 2012. Underwater Vehicle Localization with Complementary filter: Performance Analysis in the Shallow Water Environment. Journal of Intelligent Robotic Systems, 68, 373-386. 